\title{
Originals
}

\section{Gastric Inhibitory Polypeptide (GIP) and Insulin in Obesity: Increased Response to Stimulation and Defective Feedback Control of Serum Levels}

\author{
W. Creutzfeldt, R. Ebert, B. Willms ${ }^{1}$, H. Frerichs, and J. C. Brown ${ }^{2}$ \\ Division of Gastroenterology and Metabolism, Department of Medicine, University of Göttingen, FRG
}

Summary. To investigate the possibility that an abnormality of the entero-insular axis is responsible for the hyperinsulinaemia of obesity, serum immunoreactive gastric inhibitory polypeptide (IRGIP) and insulin (IRI) were measured after the ingestion of a liquid mixed test meal, glucose or fat, in normal weight and obese subjects. The latter were divided into a group with normal oral glucose tolerance (nOGT) and a group with pathological glucose tolerance (pOGT). Fasting levels of IR-GIP were significantly elevated in the obese group with pOGT. After the mixed meal the overweight subjects showed a significantly greater response of IRGIP than the controls, with highest levels in the pOGT group. Simultaneously, the IRI response was significantly greater in the obese subjects than in the controls. The increases of IR-GIP and IRI after an oral load of $100 \mathrm{~g}$ glucose were normal in the obese subjects, but showed a significantly greater integrated response in the obese patients with pOGT. The ingestion of $100 \mathrm{~g}$ fat induced no IRI release but a significantly greater release of IR-GIP in the obese subjects, irrespective of their glucose tolerance. It is concluded that fat is a stronger releaser of IR-GIP than glucose. The effect of a combined load of glucose $(30 \mathrm{~g})$ and fat $(100 \mathrm{~g})$ was also compared in obese and normal weight subjects with the effect of either alone. Fat but not glucose released significantly more IR-GIP in obese subjects. In normal weight controls, but not in obese subjects, the IRGIP release after fat plus glucose became significantly smaller than after fat alone. Since only the combined ingestion of glucose and fat and not fat alone releases insulin it is suggested that endoge-

\footnotetext{
I Fachklinik für Diabetes und Stoffwechselkrankheiten, Bad Lauterberg im Harz, FRG

2 Department of Physiology, The University of British Columbia, Vancouver, B. C., Canada V6T 1W5
}

nous insulin inhibits GIP release and that this feedback control between insulin and GIP is defective in patients with obesity.

Key words: GIP release, insulin release, obesity, pathological glucose tolerance, feedback control of GIP secretion, test meal, triglyceride ingestion, oral glucose load.

Obesity is accompanied by hyperinsulinaemia, both in the fasting state and following stimulation of insulin release $[1,2,3,4]$, and by resistance to both endogenous and exogenous insulin $[5,6,7]$. Insulin resistance of obese subjects has been explained by the decreased number of insulin receptors as a consequence of the hyperinsulinaemia $[8,9,10]$. The origin of the hyperinsulinaemia, however, is still not understood.

A possible explanation is over-activity of the entero-insular axis, i.e. an exaggerated release of a gastrointestinal factor capable of releasing insulin. To date, gastric inhibitory polypeptide (GIP) best fulfils the criteria necessary for such a factor [11]. GIP is released by the ingestion of glucose $[13,14$, $15]$, fat $[13,15,16]$ and amino acids [36]. Its capacity to potentiate glucose induced insulin release has been shown both in vivo $[13,17,18]$ and in vitro $[19,20]$.

The aim of the present investigation was to study GIP release in response to ingestion of glucose, fat and a mixed standard meal and to correlate the serum levels of immunoreactive GIP (IR-GIP) with those of immunoreactive insulin (IRI) in obese subjects with normal and pathological glucose tolerance and in normal controls. Some of the results have been presented previously in a preliminary form [21]. 


\section{Materials and Methods}

\section{a) Subjects}

Studies were carried out in 42 subjects with normal weight and normal glucose tolerance (26 male, 16 female) and 125 obese subjects (46 male, 79 female). Some subjects took part in more than one test. Informed consent was obtained from all subjects. The pertinent clinical characteristics of each group are shown in Table 1. Obesity was defined as an overweight of more than $30 \%$ above ideal body weight according to the Metropolitan Life Insurance Tables [22]. The mean age of the obese subjects was higher than the controls. However, similar results were found in age matched smaller groups in the different experimental protocols. The obese subjects were divided into two groups according to the glucose tolerance either during the test meal or during an oral glucose tolerance test with $100 \mathrm{~g}$ glucose. The oral glucose tolerance was regarded as normal (nOGT) if the 60 plus 120 min sum of blood glucose levels after ingestion of the standard meal or the oral glucose load was below $290 \mathrm{mg} / 100 \mathrm{ml}$, and as pathological (pOGT), if the sum was above $310 \mathrm{mg} / 100 \mathrm{ml}$ [12]. Subjects with fasting blood glucose levels above $130 \mathrm{mg} / 100 \mathrm{ml}$ were regarded as overt diabetics and excluded from the study.

There was no clinical or laboratory evidence of abnormal liver function in any subject. All patients were in otherwise good general health and were not taking drugs. The 42 normal weight control subjects were healthy adult volunteers, all of whom had a normal glucose tolerance and no history of diabetes in first- or second-degree relatives. All subjects studied had been on an unrestricted diet, estimated to contain more than $200 \mathrm{~g}$ of carbohydrate daily. All tests were performed in the morning $(9.00 \mathrm{~h})$ after an overnight fast.

\section{b) Protocols}

1. Test Meal: After a $45 \mathrm{~min}$ rest in the supine position an indwelling cannula was inserted into an antecubital vein and the catheter was kept patent by slow infusion of saline. Two fasting blood samples were withdrawn; further blood samples were obtained 15, 30, 45, 60, 120, 150, 180, 210, 240, 270 and $300 \mathrm{~min}$ after ingestion of the test meal. The liquid test meal contained $152 \mathrm{~g}$ carbohydrate $(18 \mathrm{~g}$ glucose, $14 \mathrm{~g}$ maltose, $12 \mathrm{~g}$ maltotriose, $52 \mathrm{~g}$ lactose, $56 \mathrm{~g}$ oligosaccharides), $30 \mathrm{~g}$ fat $(100 \mathrm{ml}$ cream $)$ and $36 \mathrm{~g}$ protein (milk powder) in a total volume of $550 \mathrm{ml}$ [23]. Blood samples were immediately placed on ice and centrifuged at $4^{\circ} \mathrm{C}$. Five aliquots of each serum sample were frozen and stored at $-20^{\circ} \mathrm{C}$, until assayed.

2. Oral Glucose Load: Instead of the test meal the subjects ingested $100 \mathrm{~g}$ glucose, dissolved in $300 \mathrm{ml}$ water. The other test conditions were as described in Protocol 1, except that blood sampling was continued for only $180 \mathrm{~min}$.

3. Oral Triglycerides: The subjects ingested $150 \mathrm{ml}$ of a suspension of corn oil (Lipomul ${ }^{\circledR}$, Upjohn Company, Kalamazoo), corresponding to $100 \mathrm{~g}$ triglyceride, within five minutes. Blood samples were obtained for $240 \mathrm{~min}$ as described in Protocol 1.

4. Comparison of Oral Glucose and Fat Load Alone and in Combination: In order to examine the influence of an oral fat load on the response of insulin and GIP to a small amount of oral glucose, the following tests were performed:

1. oral glucose load with $30 \mathrm{~g}$ glucose dissolved in $150 \mathrm{ml}$ water,

2. oral fat load ( $100 \mathrm{~g}$ triglyceride suspension as described in Protocol 3),

3 . ingestion of a mixture of $100 \mathrm{~g}$ triglycerides and $30 \mathrm{~g}$ glucose.

Sixteen obese subjects with normal glucose tolerance and 16 normal weight persons volunteered for the three experiments. The obese subjects were carefully selected and varied only by $2.2 \mathrm{~kg}$ in weight and $4 \mathrm{~cm}$ in height, with a mean ideal body weight of $142 \%$ (Table 1 ). The three tests were performed in randomized order within two weeks in each subject. Blood samples during the tests were obtained over a period of 210 min after ingestion.

\section{c) Laboratory Analysis}

Serum glucose was measured in duplicate on each sample by the glucose oxidase method immediately after separating the serum. Immunoreactive insulin (IRI) and immunoreactive GIP (IR-GIP) were determined in duplicate on each sample within four weeks of the test. Serum IRI was determined after Melani et al. [24] using human insulin as standard. Serum IR-GIP was measured by the method described by Kuzio et al. [25], with minor modifications [23]. Some additional modifications were introduced improving the sensitivity of the assay. The amount of GIP for the labelling procedure was reduced from $6 \mu \mathrm{g}$ to $3 \mu \mathrm{g}$ per label. The lower limit of sensitivity varied from assay to assay ranging from 3 to $12.5 \mathrm{pg}$. Since final serum dilution in our assays is $1: 10$, the actual sensitivity for practical determination varies from 30 to $125 \mathrm{pg} / \mathrm{ml}$ of serum. Usual- 
Table 1. The clinical data of the subjects studied ( $\mathrm{nOGT}=$ normal oral glucose tolerance; pOGT $=$ pathological oral glucose tolerance)

\begin{tabular}{|c|c|c|c|c|c|c|}
\hline & \multirow{2}{*}{$\mathrm{n}$} & \multicolumn{2}{|l|}{ Sex } & \multirow[t]{2}{*}{ Age } & \multirow{2}{*}{$\begin{array}{l}\% \text { Ideal body weight } \\
(\text { mean } \pm S E M)\end{array}$} & \multirow{2}{*}{$\begin{array}{l}\text { Positive history } \\
\text { of diabetes in first } \\
\text { degree relatives (\%) }\end{array}$} \\
\hline & & Males & Females & & & \\
\hline \multicolumn{7}{|l|}{$\begin{array}{l}\text { Test meal } \\
\text { (Protocol 1): }\end{array}$} \\
\hline Normals & 15 & 11 & 4 & $\begin{array}{l}27 \pm 6 \\
\text { (range 20-39) }\end{array}$ & $106 \pm 2$ & none \\
\hline Obese (nOGT) & 31 & 10 & 21 & $\begin{array}{l}39 \pm 5 \\
\text { (range 19-51) }\end{array}$ & $168 \pm 11$ & $48 \%$ \\
\hline Obese (pOGT) & 44 & 12 & 32 & $\begin{array}{l}44 \pm 6 \\
\text { (range 25-62) }\end{array}$ & $184 \pm 12$ & $61 \%$ \\
\hline \multicolumn{7}{|l|}{$\begin{array}{l}\text { Glucose load } \\
\text { (Protocol 2): }\end{array}$} \\
\hline Normals & 19 & 11 & 8 & $\begin{array}{l}31 \pm 5 \\
\text { (range 22-40) }\end{array}$ & $103 \pm 3$ & none \\
\hline Obese (nOGT) & 12 & 3 & 9 & $\begin{array}{l}40 \pm 5 \\
\text { (range 23-54) }\end{array}$ & $154 \pm 13$ & $37 \%$ \\
\hline Obese (pOGT) & 27 & 9 & 18 & $\begin{array}{l}42 \pm 7 \\
\text { (range 25-60) }\end{array}$ & $172 \pm 10$ & $69 \%$ \\
\hline \multicolumn{7}{|l|}{$\begin{array}{l}\text { Fat load } \\
\text { (Protocol 3): }\end{array}$} \\
\hline Normals & 21 & 12 & 9 & $\begin{array}{l}27 \pm 4 \\
\text { (range 21-34) }\end{array}$ & $107 \pm 3$ & none \\
\hline Obese (nOGT) & 15 & 3 & 12 & $\begin{array}{l}39 \pm 7 \\
\text { (range 27-59) }\end{array}$ & $149 \pm 4$ & $29 \%$ \\
\hline Obese (pOGT) & 16 & 7 & 9 & $\begin{array}{l}45 \pm 6 \\
\text { (range 29-66) }\end{array}$ & $188 \pm 11$ & $61 \%$ \\
\hline \multicolumn{7}{|l|}{$\begin{array}{l}\text { Combined load } \\
\text { with glucose } \\
\text { and fat } \\
\text { (Protocol 4): }\end{array}$} \\
\hline Normals & 16 & 10 & 6 & $\begin{array}{l}30 \pm 2 \\
\text { (range 26-35) }\end{array}$ & $99 \pm 2$ & none \\
\hline Obese & 16 & 8 & 8 & $\begin{array}{l}33 \pm 3 \\
\text { (range 26-39) }\end{array}$ & $142 \pm 0.3$ & $36 \%$ \\
\hline
\end{tabular}

ly values of less than $50 \mathrm{pg} / \mathrm{ml}$ of serum were arbitrarily considered as $50 \mathrm{pg}$ for statistical analysis. Non-specific binding was estimated in each assay for each subject and used in the calculation of the amount of immunologically active GIP in the unknown samples. The interassay variance was $13.4 \%$, the intra-assay variance $8.3 \%$ (mean of 152 assays). The GIP antiserum used in this study (Van No. 8) did not crossreact with glucagon, VIP, secretin, CCK, gut glucagon I and gastrin. Porcine GIP, prepared as described previously [26], was used as standard.

\section{d) Statistical Analysis}

All values are presented as means \pm SEM. Results were analyzed using standard statistical methods. Student's " $T$ " test for unpaired values was per- formed to compare results between the normal volunteers and the obese subjects with normal and pathological glucose tolerance. Integrated responses to the test meal for serum glucose, IR-GIP and IRI were calculated from summation of the products of the mean serum concentrations during each time period, multiplied by the number of minutes in the time period minus the product of the basal value multiplied by the total number of minutes after a test [27].

\section{Results}

\section{Fasting Levels (Table 2)}

Fasting serum levels of glucose, IRI and IR-GIP tended to be higher in obese subjects with nOGT 
than in controls, but this difference was not significant. In contrast, significantly higher basal levels were found in the obese patients with pOGT (Table 2).

\section{Response to a Mixed Test Meal (Fig. 1, Table 3)}

In normal weight subjects the serum glucose curve showed a first peak at $60 \mathrm{~min}$ and a second increase $210 \mathrm{~min}$ after ingestion of the meal. IRI and IR-GIP concentrations reached a peak $30 \mathrm{~min}$ after inges-

Table 2. Fasting levels (average of three serum samples) of IRGIP, IRI and glucose in controls and obese subjects before the test meal (Protocol 1) (nOGT = normal oral glucose tolerance; pOGT $=$ pathological oral glucose tolerance)

\begin{tabular}{lllll}
\hline Protocol & $\mathrm{n}$ & $\begin{array}{l}\text { IR-GIP } \\
(\mathrm{pg} / \mathrm{ml})\end{array}$ & $\begin{array}{l}\text { IRI } \\
(\mu \mathrm{U} / \mathrm{ml})\end{array}$ & $\begin{array}{l}\text { Glucose } \\
(\mathrm{mg} / 100 \mathrm{ml})\end{array}$ \\
\hline Controls & 15 & $266 \pm 106$ & $<6$ & $76 \pm 8$ \\
Obese nOGT & 31 & $517 \pm 182 \mathrm{~ns}$ & $7 \pm 0.7 \mathrm{~ns}$ & $84 \pm 12 \mathrm{~ns}$ \\
Obese pOGT & 44 & $742 \pm 188^{\mathrm{a}}$ & $18 \pm 4^{\mathrm{a}}$ & $98 \pm 13^{\mathrm{b}}$ \\
\hline
\end{tabular}

difference versus controls:

$\mathrm{a}=\mathrm{p}<0.05$

$\mathrm{b}=\mathrm{p}<0.02$

ns $=$ not significant tion of the test meal; IRI decreased thereafter while IR-GIP, after a minor drop, remained elevated until the end of the observation period.

The obese subjects studied were divided into two groups according to their glucose tolerance after ingestion of the test meal (see Methods). Mean integrated glucose response over $180 \mathrm{~min}$ was significantly greater in obese subjects with pOGT than in controls and obese subjects with nOGT. The latter were not significantly different from controls (Table 3).

Serum insulin in response to the test meal rose higher in obese subjects with nOGT than in normal subjects (peak at $30 \mathrm{~min}$ in normals $91 \pm 16 \mu \mathrm{U} / \mathrm{ml}$, in obese subjects with nOGT peak at 60 min 178 $\pm 30 \mu \mathrm{U} / \mathrm{ml} ; \mathrm{p}<0.01$; Fig. 1) and was highest, although with markedly delayed peak in the obese subjects with pOGT (peak at 90 min $217 \pm 46$ $\mu \mathrm{U} / \mathrm{ml} ; \mathrm{p}<0.005$ ). The integrated IRI response over $180 \mathrm{~min}$ in the obese subjects was significantly greater than in the controls. No difference existed between obese subjects with nOGT and pOGT (Table 3).

Upon ingestion of the test meal IR-GIP levels rose rapidly in obese subjects with normal and

Table 3. Integrated response $(180 \mathrm{~min})$ of serum levels of IR-GIP, IRI and glucose following different stimuli in normals and obese subjects. (nOGT $=$ normal oral glucose tolerance; pOGT $=$ pathological oral glucose tolerance. See Methods for calculation of integrated response)

\begin{tabular}{|c|c|c|c|c|c|c|c|c|c|}
\hline & \multicolumn{3}{|c|}{$\begin{array}{l}\text { IR-GIP } \\
(\mathrm{ng} / \mathrm{ml} \cdot 180 \mathrm{~min})\end{array}$} & \multicolumn{3}{|c|}{$\begin{array}{l}\text { IRI } \\
(\mathrm{mU} / \mathrm{ml} \cdot 180 \mathrm{~min})\end{array}$} & \multicolumn{2}{|r|}{$\begin{array}{l}\text { Glucose } \\
(\mathrm{g} / 100 \mathrm{ml} .\end{array}$} & $180 \mathrm{~min})$ \\
\hline $\begin{array}{l}\text { Controls } \\
(\mathrm{n}=15) \\
\text { Obese (nOGT) } \\
(\mathrm{n}=31) \\
\text { Obese (pOGT) } \\
(\mathrm{n}=44)\end{array}$ & $<0.005$ & {$\left[\begin{array}{c}106.2 \pm 9.6 \\
338.9 \pm 40.6 \\
580.6 \pm 67.4\end{array}\right]$} & $\begin{array}{l}<0.005 \\
<0.01\end{array}$ & $<0.01$ & {$\left[\begin{array}{c}8.7 \pm 0.9 \\
25.4 \pm 3.1 \\
-25.2 \pm 3.5\end{array}\right]$} & $\begin{array}{l}<0.01 \\
\text { n. s. }\end{array}$ & $<0.005$ & {$\left[\begin{array}{c}3.8 \pm 0.5 \\
5.0 \pm 0.9 \\
16.3 \pm 2.4\end{array}\right]$} & $\begin{array}{l}\text { n. s. } \\
<0.01\end{array}$ \\
\hline \multicolumn{10}{|l|}{$\begin{array}{l}\text { Glucose } \\
\text { load }(100 \mathrm{~g})\end{array}$} \\
\hline $\begin{array}{l}\text { Controls } \\
(\mathrm{n}=19) \\
\text { Obese (nOGT) } \\
(\mathrm{n}=12) \\
\text { Obese (pOGT) } \\
(\mathrm{n}=27)\end{array}$ & $<0.01$ & {$\left[\begin{array}{c}82.9 \pm 8.4 \\
94.6 \pm 10.2 \\
\\
147.5 \pm 14.3\end{array}\right]$} & $\begin{array}{l}\text { n. s. } \\
<0.05\end{array}$ & $<0.01$ & {$\left[\begin{array}{c}6.2 \pm 0.7 \\
8.6 \pm 1.2 \\
12.5 \pm 1.5\end{array}\right]$} & $\begin{array}{l}\text { n. s. } \\
<0.05\end{array}$ & $<0.005$ & {$\left[\begin{array}{c}6.4 \pm 0.7 \\
8.5 \pm 0.9 \\
16.9 \pm 1.8\end{array}\right]$} & $\begin{array}{l}\text { n. s. } \\
<0.01\end{array}$ \\
\hline \multicolumn{10}{|l|}{ Fat load $(100 \mathrm{~g})$} \\
\hline $\begin{array}{l}\text { Controls } \\
(\mathrm{n}=21)\end{array}$ & & {$[175.9 \pm 18.6]$} & $<0.005$ & & 0 & & & $-0.6 \pm 0.07$ & \\
\hline $\begin{array}{l}\text { Obese }(\mathrm{nOGT}) \\
(\mathrm{n}=15)\end{array}$ & $<0.005$ & $376.8 \pm 39.4$ & n.s. & & $1.0 \pm 0.2$ & & & $-0.5 \pm 0.08$ & \\
\hline $\begin{array}{l}\text { Obese (pOGT) } \\
(\mathrm{n}=16)\end{array}$ & & $L_{414.2 \pm 0.3}$ & & & $1.8 \pm 0.6$ & & & $-0.8 \pm 0.12$ & \\
\hline
\end{tabular}




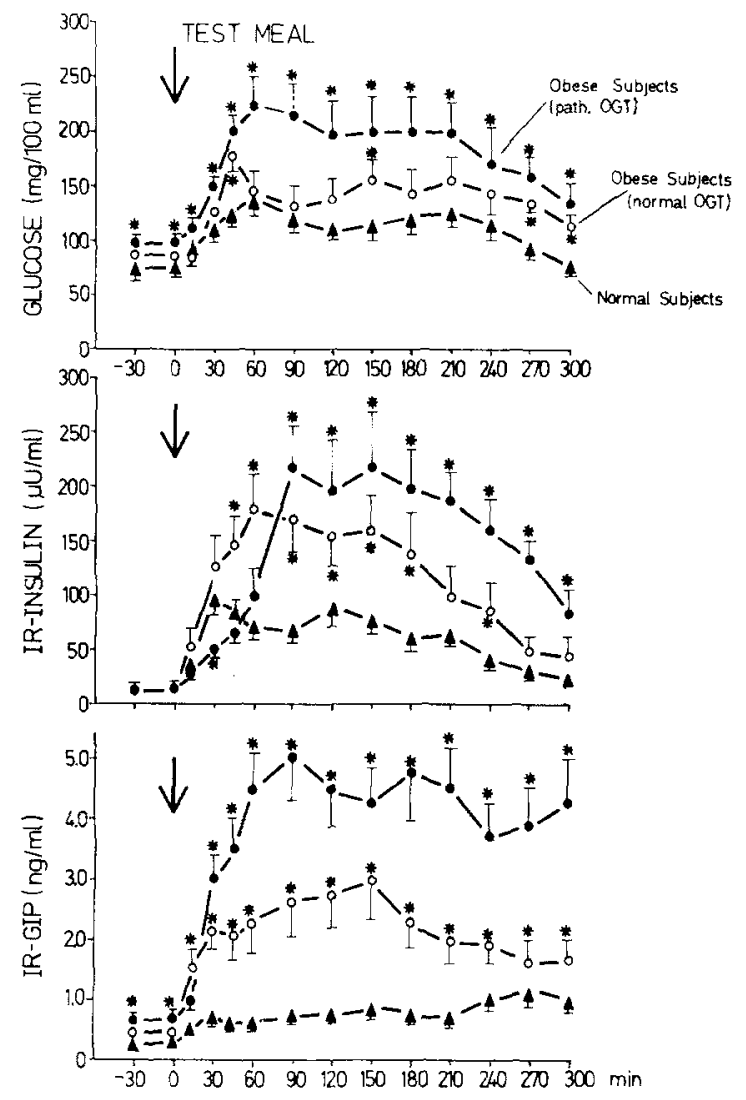

Fig. 1. Increase of serum levels of IR-GIP, IRI and glucose in 15 normals $(\mathbf{A})$, 31 obese subjects with normal glucose tolerance $(0-0)$ and 44 obese subjects with pathological glucose tolerance (-—) after ingestion of a mixed liquid test meal given at $0 \mathrm{~min}$. Significant differences versus normal subjects are indicated (* $=p<0.02$ and less). For detals see Methods, Pro tocol 1

pathological OGT and far exceeded the levels observed in normal subjects. Sixty min after beginning the test IR-GIP levels were about double (4648 $\pm 568 \mathrm{pg} / \mathrm{ml}$ ) the levels observed in obese subjects with nOGT $(2269 \pm 386 \mathrm{pg} / \mathrm{ml})$ and about four- to fivefold those of normal subjects $(816 \pm 114$ $\mathrm{pg} / \mathrm{ml}$ ). The integrated IR-GIP levels over $180 \mathrm{~min}$ were significantly greater in obese subjects with nOGT than in controls and in obese subjects with pOGT significantly greater than in obese subjects with nOGT (Table 3 ).

\section{Response to an Oral Glucose Load (Fig. 2,} Table 3)

Figure 2 shows the IRI, IR-GIP and serum glucose responses to an oral glucose load. Serum glucose levels increased in the obese group with pOGT to significantly higher levels after the glucose load. The integrated glucose response over $180 \mathrm{~min}$ was also significantly greater, in contrast to the group with

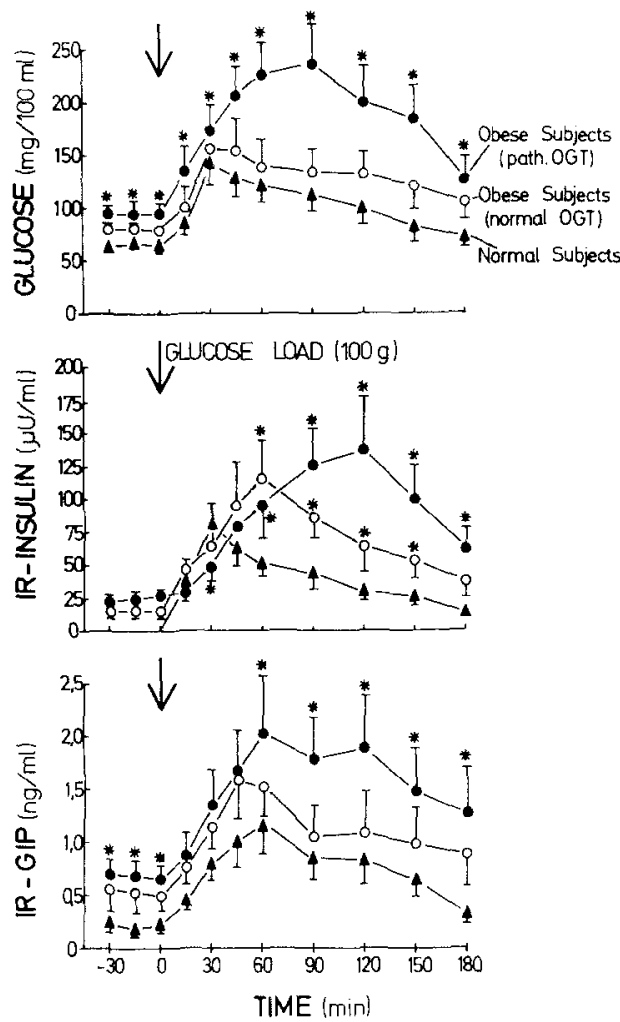

Fig. 2. Increase of serum levels of IR-GIP, IRI and glucose in 19 normals $(\boldsymbol{\Lambda}-\mathbf{\Lambda}), 12$ obese subjects with normal glucose tolerance $(\mathrm{o}-\mathrm{o})$ and 27 obese subjects with pathological glucose tolerance (- $\bullet$ ) following ingestion of $100 \mathrm{~g}$ glucose at $0 \mathrm{~min}$. Significant differences versus normal subjects are indicated $(*=p<0.02$ and less). For details see Methods, Protocol 2

nOGT (Table 3). Serum IRI showed a delayed increase after glucose ingestion in both obese groups. A delayed return of IRI levels to baseline was most marked in the obese pOGT group, but was also present in obese subjects with nOGT. The integrated response of serum IRI over $180 \mathrm{~min}$ in the obese persons with pOGT was significantly greater than in obese subjects with nOGT and controls, while the latter were not significantly different from each other.

Obese subjects with pOGT exhibited a significantly greater IR-GIP response to glucose than normal subjects, reaching a peak at $60 \mathrm{~min}(2042$ $\pm 501 \mathrm{pg} / \mathrm{ml}$ ). In the obese nOGT group the IRGIP response to the glucose load was not significantly different from that of the control subjects. Correspondingly, the integrated IR-GIP response over $180 \mathrm{~min}$ was significantly greater than in the controls only in obese subjects with pOGT (Table 3). 


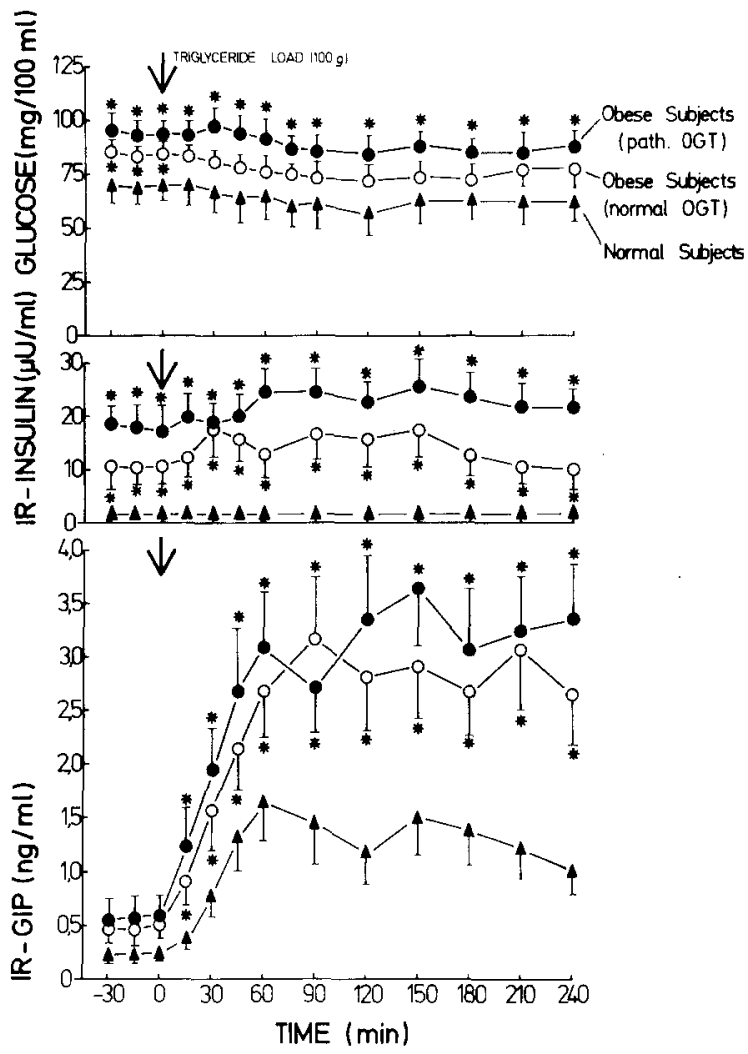

Fig. 3. Increase of serum levels of IR-GIP, IRI and glucose in 21 normals $(\boldsymbol{\Lambda}-\mathbf{A}), 15$ obese subjects with normal glucose tolerance $\left(\mathrm{o}_{-} \mathrm{o}\right)$ and 16 obese subjects with pathological glucose tolerance $(-\bullet)$ following ingestion of $100 \mathrm{~g}$ triglyceride at $0 \mathrm{~min}$. Significant differences versus normal subjects are indicated $(*=p<0.02$ and less). For details see Methods, Protocol 3

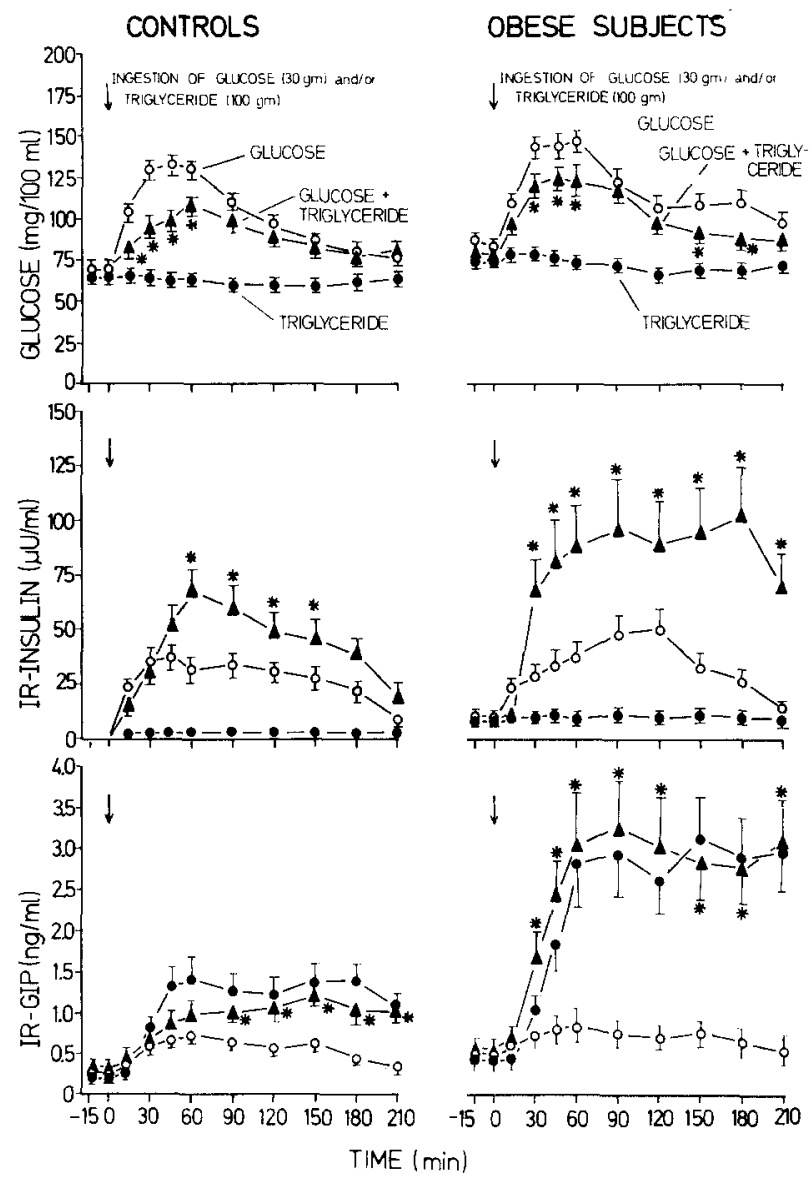

Fig. 4. Increase of serum levels of IR-GIP, IRI and glucose to the ingestion of $30 \mathrm{~g}$ glucose $(\mathrm{o}-\mathrm{o}), 100 \mathrm{~g}$ triglyceride $(\bullet-\bullet)$ and $30 \mathrm{~g}$ glucose plus $100 \mathrm{~g}$ triglyceride $(\boldsymbol{\Lambda}-\boldsymbol{\Lambda})$ in the same normal weight controls ( $\mathrm{n}=16)$ and obese $(42 \%$ overweight) subjects with normal glucose tolerance $(n=16)$. Significant differences between glucose and glucose plus triglyceride are indicated $\left(^{*}=p<0.02\right.$ or less). For details see Methods, Protocol 4

Table 4. Integrated response $(180 \mathrm{~min})$ of serum levels of IR-GIP, IRI and glucose to the ingestion of $1.30 \mathrm{~g}$ glucose, $2.30 \mathrm{~g}$ glucose plus $100 \mathrm{~g}$ triglyceride and $3.100 \mathrm{~g}$ triglyceride in the same normal weight controls $(\mathrm{n}=16)$ and obese $(42 \%$ overweight) subjects with normal glucose tolerance $(n=16)$. (see Methods for calculation of integrated response)

\begin{tabular}{llcc}
\hline & $\begin{array}{l}\text { IRI-GIP } \\
(\mathrm{ng} / \mathrm{ml} \cdot 180 \mathrm{~min})\end{array}$ & $\begin{array}{l}\text { IRI } \\
\mathrm{mU} / \mathrm{ml} \cdot 180 \mathrm{~min})\end{array}$ & $\begin{array}{l}\mathrm{Glucose} \\
(\mathrm{g} / 100 \mathrm{ml} \cdot 180 \mathrm{~min})\end{array}$ \\
\hline $\begin{array}{l}\text { 1. Glucose } \\
\text { Controls }\end{array}$ & $40.2 \pm 4.8$ & $3.9 \pm 0.5$ & $6.1 \pm 0.6$ \\
Obese & $40.8 \pm 5.9$ & $4.6 \pm 0.6$ & $8.1 \pm 0.9$ \\
2. Glucose plus fat & & & $3.9 \pm 0.5^{\mathrm{b}}$ \\
Controls & $102.3 \pm 12.3^{\mathrm{b}}$ & $7.5 \pm 0.8^{\mathrm{b}}$ & $4.5 \pm 0.6^{\mathrm{b}}$ \\
Obese & $387.9 \pm 44.1^{\mathrm{a}} \mathrm{b}$ & $15.9 \pm 1.9^{\mathrm{a}, \mathrm{b}}$ & \\
3. Fat & & & \\
Controls & $159.8 \pm 18.6^{\mathrm{c}}$ & & \\
Obese & $368.4 \pm 48.1^{\mathrm{a}}$ & & \\
\hline
\end{tabular}

significant differences:

$\mathrm{p}<0.01$ or less compared with the respective controls

b $\mathrm{p}<0.02$ or less compared with glucose alone

${ }^{c} \mathrm{p}<0.05$ compared with glucose plus fat 
4. Response to an Oral Triglyceride Load (Fig. 3, Table 3)

A slight, but not significant, decrease of serum glucose occurred in the control subjects after ingestion of $100 \mathrm{~g}$ fat. In both obese groups significantly higher fasting serum glucose levels were observed compared to normal weight subjects. They declined slightly during the triglyceride load.

The IRI levels of obese subjects were significantly higher than in normal weight controls. Following fat ingestion a small and transient rise of serum IRI occurred in both obese groups. However, this increase was not significant at any time.

The IR-GIP levels rose significantly from a mean basal value of $249 \pm 61 \mathrm{pg} / \mathrm{ml}$ to 762 $\pm 201 \mathrm{pg} / \mathrm{ml} 30 \mathrm{~min}$ after ingestion of fat in normal subjects, reaching a peak of $1658 \pm 311 \mathrm{pg} / \mathrm{ml}$ at $60 \mathrm{~min}$ and remaining above $1 \mathrm{ng} / \mathrm{ml}$ until $240 \mathrm{~min}$.

Obese subjects responded to the oral triglyceride load with an exaggerated IR-GIP increase. This IRGIP response was significantly higher at $15 \mathrm{~min}$ in both obese groups than in normal weight controls and remained so for $240 \mathrm{~min}$. The peak value of serum IR-GIP, achieved by the fat load, was 3651 $\pm 521 \mathrm{pg} / \mathrm{ml}$ in the obese group with pOGT and $3201 \pm 618 \mathrm{pg} / \mathrm{ml}$ in the obese group with nOGT. The integrated IR-GIP responses of the two obese groups were the same and both were significantly higher than in the controls (Table 3 ).

\section{Comparison of Oral Glucose and Fat Load Alone and in Combination (Fig. 4, Table 4)}

In order to elucidate the interplay between serum levels of glucose, IRI and IR-GIP in normal and obese subjects a small dose of glucose $(30 \mathrm{~g})$ and a large fat load ( $100 \mathrm{~g}$ triglycerides) were given alone and in combination. The function of the small glucose load was to initiate insulin release. All three tests were performed in the same normal weight and obese subjects with normal glucose tolerance.

The serum glucose levels in normal weight and obese subjects did not change after $100 \mathrm{~g}$ fat, but increased after $30 \mathrm{~g}$ glucose. This increase was smaller if glucose was given together with triglycerides. The integrated glucose increase was not statistically different between controls and obese subjects. However, in both groups it was significantly smaller after the combined glucose-fat load than after glucose alone (Table 4).

Serum levels of IRI did not change after fat ingestion but increased after $30 \mathrm{~g}$ glucose. If glucose was given together with fat, significantly more IRI was released in both controls and obese subjects.
The integrated IRI response after the combined load was significantly greater in obese subjects than in normal weight controls (Table 4).

The increase of IR-GIP serum levels after $30 \mathrm{~g}$ glucose was small and of the same magnitude in controls and obese subjects. The IR-GIP increase after $100 \mathrm{~g}$ fat was much larger and significantly greater in obese subjects than in normal weight controls. If glucose and fat were given together, the IRGIP increase of normal weight controls was significantly lower than after fat alone. The suppression of fat induced IR-GIP release by glucose did not occur in obese subjects. This can be seen clearly when comparing the integrated responses (Table 4).

\section{Discussion}

A significantly increased response of serum levels of IR-GIP and IRI to a high caloric test meal has been observed in obese subjects. Furthermore, this response was significantly greater in obese subjects with glucose intolerance than in obese subjects with normal OGT. After ingestion of glucose the response of IR-GIP and IRI was less and reached significance only in the obese group with glucose intolerance. The delayed increase of serum IRI in obesity (especially in the presence of glucose intolerance) was compensated by a sustained elevation of IRI. Thus, the integrated IR-GIP response over 180 min was generally directly correlated to the integrated IRI response (Table 3 ). However, this relationship was obscured because the GIP levels attained represent the net effect of stimulation and inhibition of GIP release.

After ingestion of triglycerides the IR-GIP response was significantly greater in obese subjects than in normal weight controls. However, there was no difference between obese subjects with nOGT and pOGT. The IR-GIP response to fat ingestion was not accompanied by an increase of serum IRI levels and serum glucose levels did not change.

Some of the results confirm earlier work of Brown et al. [13] and Cataland et al. [14, 16] who demonstrated IR-GIP release after glucose and fat and showed that serum glucose must be raised for GIP to be insulinotrophic.

\section{Exaggerated GIP Response in Obesity}

Despite the well established hyperinsulinaemia in obesity $[1,2,3,4]$ the possibility that an overactive entero-insular axis is involved in the pathogenesis of insulin hypersecretion has received little attention. 
In non-diabetic obese persons after glucose ingestion Cataland [31] and Bloom [32] found a normal GIP (and IRI) response to an oral glucose load, but an exaggerated GIP release in obese maturity onset diabetes [30, 32].

These findings are in agreement with our results (Fig. 2, Table 3). Our data suggest that glucose is not a strong enough stimulus to GIP release to uncover hypersecretion of GIP (and IRI) in obese subjects with nOGT. This has been achieved in the present study by ingestion of triglycerides and a mixed high caloric test meal. It was previously reported that fat absorption increased glucose induced insulin release while fat ingestion in the absence of glucose only inconsistently elicited small amounts of insulin [33]. The IR-GIP response to fat and the mixed test meal was significantly greater in obese subjects than in normal weight controls, as was the IRI response after the test meal. In these conditions serum glucose levels were elevated and the time courses of the IR-GIP and IRI release were closely related.

Therefore, a causal relationship between the exaggerated IRI response to the test meal and the IRGIP response is conceivable. The elevated fasting IRI levels characteristic of obesity $[1,2,3,4]$ and the augmented insulin secretion of obese persons, even after intravenous glucose injection [28, 29], which does not alter basal IR-GIP levels [13], could be explained as secondary phenomena: B-cell stimulation (due to increased postprandial GIP levels) induces islet cell hyperplasia [35] and insulin resistance $[5,6]$ i. e. decreased numbers of insulin receptors [10]. The exaggerated response of the GIP producing cells to stimulation by different nutrients in obesity is unknown. A larger number of GIP producing cells as described in obese hyperglycaemic mice [39] is not very probable because the augmented GIP response is reversible by starvation or caloric restriction for a few days [21].

It may be that the high caloric intake of obese persons conditions the GIP producing cells for better GIP release. In this case the exaggerated GIP response to ingestion of food in obese subjects would be only a symptom of obesity.

\section{Additional Enhancement of GIP Response by Glucose Intolerance}

Since the IR-GIP release is different in obese subjects with and without pathological oral glucose tolerance it can be concluded that glucose intolerance (subclinical or chemical diabetes) as such affects the GIP response to different stimuli. The significantly larger IR-GIP response of obese subjects to a test meal is further enhanced by the presence of glucose intolerance. After an oral glucose load, which is a weak stimulus for GIP release, the IR-GIP response was significantly greater only in the obese subjects with glucose intolerance.

After a glucose load an augmented IR-GIP release has been described in maturity onset diabetes independent of the presence of obesity $[13,30,38]$, while Bloom [32] found this only in obese diabetics (breakfast or glucose load). The reason for this discrepancy seems to be a methodological one. The antibody used by the former authors $[13,30,38]$ and the technique of their radioimmunoassay is basically the same as applied in this study.

A possible explanation for the relationship between the IR-GIP response and glucose tolerance is an interaction between the GIP producing cells and the serum insulin levels.

In the case of glucose intolerance of subclinical or overt maturity onset diabetes insulin release to any stimulus (orally or intravenously) is delayed. This holds true also for the stimulation by endogenous response of GIP, which increased sharply after glucose or the test meal in diabetics, as well as in healthy controls, indicating that the primary defect of the B-cell leading to the delayed insulin response cannot be overcome by IR-GIP. If insulin inhibits GIP release in the sense of a feedback control [13, $15,34]$ a delayed insulin release would result in less inhibition, i. e. an exaggerated initial IR-GIP release and this could account for the additional IR-GIP response when obese subjects become diabetic.

The sustained elevation of IR-GIP levels needs further explanation because the delayed IRI increase is later followed by a sustained IRI response (Fig. 1). In case of an intact feedback control between insulin and GIP release the GIP levels should not be elevated for such a long time.

\section{Defective Feedback Control of GIP Release by Insulin in Obesity}

Brown et al. [13], Cleator and Gourlay [15] and Crockett et al. [34] have demonstrated that the infusion of glucose or insulin lowers the fat induced IRGIP release and suggested a negative feedback control between serum IRI level and GIP secretion. Some of the data presented here support this hypothesis. The different IR-GIP response after the test meal and fat ingestion (Table 3 ) can well be interpreted by feedback control of IR-GIP release by insulin. Both are strong stimuli for IR-GIP release as can be seen from the maximal values elicited. However, in normals less IR-GIP is released after the test meal than after triglyceride ingestion while in obese persons with pOGT the test meal releases 
more IR-GIP than fat alone. Since the largest IRGIP response has been achieved with the test meal in obese subjects with pOGT the high caloric mixed test meal seems to be the stronger stimulus. The reason for a smaller IR-GIP response to the test meal in normal weight controls (and to a lesser degree also in obese subjects with nOGT) can be explained by the IRI increase which occurs only after the carbohydrate containing test meal and not after triglyceride ingestion and which prevents a maximal GIP response from being elicited. After oral fat load no IRI release occurs and the IR-GIP response is not modulated by insulin feedback control.

The results of sequential oral loads with triglycerides, glucose and both together in the same normal and obese subjects with nOGT (Table 4) give strong support for the existence of a feedback control of GIP release and insulin secretion and a defect of this mechanism in obesity. The combination of the two stimuli produced in both groups a significantly larger IRI response than glucose alone. This induced in the normal controls a lowering of the IR-GIP response (intact feedback control) and in the obese patients no change of the IR-GIP response (defective feedback control). Since only the serum IRI levels and not the glucose response were different between the controls and obese subjects after the combined oral load the negative feedback control seems to be mediated by insulin and not by glucose. However, this question needs further clarification.

A possible mechanism for this defect in feedback control in obesity could be via a decreased responsiveness of the GIP producing cells to insulin due to a decreased number of insulin receptors [9] of the GIP cells. A further decrease in receptor population could explain the exaggerated findings in obesity with glucose intolerance. The reversibility of the exaggerated GIP response in obesity [21] and in maturity onset diabetes [37] by treatment and some of the results of this study support such a contention. Fluctuation of the concentration of insulin receptors induced by treatment have been described [10]. Thus, the exaggerated levels of IR-GIP in obesity would at first be a symptom rather than the cause of obesity.

However, since GIP potentiates glucose induced insulin release the elevated GIP levels later become an important factor in the pathogenesis of further lipogenesis.

Acknowledgement. The authors want to thank Mrs. K. Illmer and Mrs. B. Hillebrecht for their expert technical assistance. This work was supported by the Deutsche Forschungsgemeinschaft, Bonn-Bad-Godesberg, grant $\mathrm{Cr} 20 / 7$ (12) and grant 41/3208 Brown.

\section{References}

1. Karam, J.H., Grodsky, G.M., Forsham, P.H.: Excessive insulin response to glucose in obese subjects as measured by immunochemical assay. Diabetes 12, 197-205 (1963)

2. Yalow, R. S., Glick, S. M., Roth, J., Berson, S. A.: Plasma insulin and growth hormone levels in obesity and diabetes. Ann. N. Y. Acad. Sci. 131, 357-373 (1965)

3. Bagdade, J. D., Bierman, E. L., Porte, D.: The significance of basal insulin in the evaluation of the insulin response to glucose in diabetic and non diabetic subjects. J. Clin. Invest. 46, 1549-1557 (1967)

4. Kreisberg, R. A., Boshell, B.R., Di Placido, J., Roddam, R. F.: Insulin secretion in obesity. N. Engl. J. Med. 276, 314-319 (1967)

5. Rabinowitz, D., Zierler, K. L.: Forearm metabolism in obesity and its response to intra-arterial insulin. Characterization of insulin resistance and evidence for adaptive hyperinsulinism. J. Clin. Invest. 41, 2173-2182 (1962)

6. Perley, M.J., Kipnis, D.M.: Plasma insulin response to glucose and tolbutamide of normal weight and obese diabetic and nondiabetic subjects. Diabetes 15, 867-874 (1966)

7. Colwell, J.A., Lein, A.: Diminished insulin response to hyperglycemia in prediabetes and diabetes. Diabetes 16, 560-565 (1967)

8. De Meyts, P., Bianco, A.R., Roth, J.: Site-site interactions among insulin receptors. Characterization of the negative cooperativity. J. Biol. Chem. 251, 1877-1888 (1976)

9. Roth, J., Kahn, R., Lesniak, M. A., Gorden, P., De Meyts, P., Megyesi, K., Neville, Jr., D. M., Gavin, J.R., Soll, A.H., Freychet, P., Goldfine, I. D., Bar, R. S., Archer, J. A.: Receptors for insulin, NSILA-s, and growth hormone: application to disease states in man. Recent Prog. Horm. Res. 31, 95-139 (1975)

10. Bar, R.S., Gorden, P., Roth, J., Kahn, R., De Meyts, P.: Fluctuations in the affinity and concentration of insulin receptors on circulating monocytes of obese patients. Effects of starvation, refeeding, and dieting. J. Clin. Invest. 58, 1123-1135 (1976)

11. Creutzfeldt, W.: Insulin-releasing factors of the gastrointestinal mucosa (incretin). Gastroenterology 67, 748-750 (1974)

12. Köbberling, J., Creutzfeldt, W.: Comparison of different methods for the evaluation of the oral glucose tolerance test. Diabetes 19, 870-877 (19 (1970)

13. Brown, J. C., Dryburgh, J. R., Ross, S. A., Dupré, J.: Identification and actions of gastric inhibitory polypeptide. Recent Prog. Horm. Res. 31, 487-532 (1975)

14. Cataland, S., Crockett, S. E., Brown, J.C., Mazzaferri, E. L.: Gastric inhibitory polypeptide (GIP) stimulation by oral glucose in man. J. Clin. Endocrinol. Metab. 39, 223-228 (1974)

15. Cleator, J.G. M., Gourlay, R.H.: Release of immunoreactive gastric inhibitory polypeptide (IR-GIP) by oral ingestion of food substances. Am. J. Surg. 130, 128-135 (1975)

16. Falko, J.M., Crockett, S.E., Cataland, S., Mazzaferri, E. L.: Gastric inhibitory polypeptide (GIP) stimulated by fat ingestion in man. J. Clin. Endocrinol. Metab. 41, 260-265 (1975)

17. Pederson, R.A., Schubert, H.E., Brown, J.C.: Gastric inhibitory polypeptide. Its physiologic release and insulinotropic action in the dog. Diabetes 24, 1050-1056 (1975)

18. Dupré, J., Ross, S. A., Watson, D., Brown, J. C.: Stimulation of insulin secretion by gastric inhibitory polypeptide in man. J. Clin. Endocrinol. Metab. 37, 826-828 (1973)

19. Schauder, P., Brown, J.C., Frerichs, H., Creutzfeldt, W.: Gastric inhibitory polypeptide: effect on glucose-induced insulin release from isolated rat pancreatic islets in vitro. Diabetologia 11, 483-484 (1975)

20. Pederson, R.A., Brown, J.C.: The insulinotropic action of 
gastric inhibitory polypeptide in the perfused isolated rat pancreas. Endocrinology 99, 780-785 (1976)

21. Ebert, R., Willms, B., Brown, J.C., Creutzfeldt, W.: Serum gastric inhibitory polypeptide (GIP) levels in obese subjects and after weight reduction. Eur. J. Clin. Invest. 6, 327 (1976)

22. Documenta Geigy Scientific Tables: 6th ed., p. 624. Manchester: Geigy 1962

23. Creutzfeldt, W., Ebert, R., Arnold, R., Frerichs, H., Brown, J. C.: Gastric inhibitory polypeptide (GIP), gastrin, and insulin: response to test meal in coeliac disease and after duodenopancreatectomy. Diabetologia 12, 279-286 (1976)

24. Melani, F., Ditschuneit, H., Bartelt, K.M., Friedrich, H., Pfeiffer, E.F.: Über die radioimmunologische Bestimmung von Insulin im Blut. Klin. Wochenschr. 43, 1000-1007 (1965)

25. Kuzio, M., Dryburgh, J.R., Malloy, K.M., Brown, J.C.: Radioimmunoassay for gastric inhibitory polypeptide. Gastroenterology 66, 357-364 (1974)

26. Brown, J.C., Mutt, V., Pederson, R. A.: Further purification of a polypeptide demonstrating enterogastrone activity. J. Physiol. (Lond.) 209, 57-64 (1970)

27. Stern, D.H., Walsh, J.H.: Gastrin release in postoperative ulcer patients: evidence for release of duodenal gastrin. Gastroenterology 64, 363-369 (1973)

28. Pelkonen, R., Nikkilä, E. A., Taskinen, M. R., Mietinnen, T.: Plasma insulin (IRI) response to small doses of intravenous glucose: influence of obesity and fasting. Scand. J. Clin. Lab. Invest. 21 (Suppl. 101), 25 (1968)

29. Jacot, J.P., Zuppinger, K.A., Joss, E.E., Donath, A.: Evidence for two types of juvenile obesity on the basis of body composition and insulin release following small doses of glucose. Klin. Wochenschr. 51, 1109-1114 (1973)

30. Crockett, S.E., Mazzaferri, E.L., Cataland, S.: Gastric inhibitory polypeptide in maturity-onset diabetes mellitus. Diabetes 25, 931-935 (1976)

31. Cataland, S.: Discussion to Brown et al. Recent Prog. Horm. Res. 31, 526-528 (1975)

32. Bloom, S. R.: GIP in diabetes. Diabetologia 11, 334 (1975)
33. Böttger, I., Dobbs, R.E., Faloona, G. R., Unger, R.H.: The effects of triglyceride absorption upon glucagon, insulin and gut glucagon-like immunoreactivity. J. Clin. Invest. 52, 2532-2539 (1973)

34. Crockett, S. E., Cataland, S., Falko, J.M., Mazzaferri, E. L.: The insulinotropic effect of endogenous gastric inhibitory polypeptide in normal subjects. J. Clin. Endocrinol, Metab. 42, 1098-1103 (1976

35. Ogilvie, R.: Sugar tolerance in obese subjects: a review of 65 cases. Q. J. Med. 28, 345-358 (1935)

36. Thomas, F.B., Mazzaferri, E., Crockett, S.E., Mekhjiam, H. S., Gruemer, H. D., Cataland, S.: Stimulation of secretion of gastric inhibitory polypeptide and insulin by intraduodenal amino acid perfusion. Gastroenterology 70, 523-527 (1976)

37. Creutzfeldt, W., Ebert, R.: Release of gastric inhibitory polypeptide (GIP) to a test meal under normal and pathological conditions in man. Proceedings of the 9th Congress of the International Diabetes Federation, New Delhi 1976. Amsterdam: Excerpta Medica (in press)

38. Ebert, R., Frerichs, H., Creutzfeldt, W.: Serum gastric inhibitory polypeptide (GIP) response in patients with maturity onset diabetes and in juvenile diabetics. Diabetologia 12, 388 (1976)

39. Polak, J. M., Pearse, A. G. E., Grimelius, L., Marks, V.: Gastrointestinal apudosis in obese hyperglycemic mice. Virchows Archiv [Cell Pathol.] 19, 135-150 (1975)

Received: May 11, 1977, and in revised form:

August 4, 1977

Prof. Dr. med. W. Creutzfeldt

Medizinische Universitätsklinik

Humboldtallee 1

D-3400 Göttingen

Federal Republic of Germany 